Endocrinol. Japon. 1963, 10 (3), 169 174

\title{
BREEDING OF MICE WITH SPONTANEOUS ALVEOLAR FORMATION IN THE MAMMARY GLAND \\ II. RELATIONSHIP BETWEEN THE SPONTANEOUS ALVEOLAR FORMATION AND ESTROUS GYCLE
}

\author{
HARUO KOBAYASHI, JIRO NAGAI AND MOTOO NAITO \\ Department of Animal Breeding, Faculty of Agriculture, \\ University of Tokyo, Tokyo
}

The hormonal researches on the development of mammary gland has been conducted for several decades and it has become clear that estrogen is essentially responsible for the development of the duct system, whereas that of lobules and alveoli is dependent on progesterone. In mice, general observation on the mammary growth is that only the duct system develops in virgins and the lobulealveolar system is seen after coitus, either sterile or fertile. However, some strains of mice showed lobule-alveolar formation even at the virgin stage. Khanolker and Ranadiv (1947) reported that there was a noticeable difference in the structure of the mammary glands of virgin mice at 7 to 8 months of age in the 3 strains $\mathrm{C}_{3} \mathrm{H}$, Strong $A$ and $\mathrm{C}_{57}$ Black and that 13 out of $20 \mathrm{C}_{3} \mathrm{H}$ virgins had an uneven multiplication of acinar buds. Nandi (1958 and 1959) reported that among $\mathrm{C}_{3} \mathrm{H} /$ HeCrgl, approximately $25 \%$ of the 12 -weeks-old virgin females had the mammary glands with fully developed lobule-alveolar system. Nagai (1962) showed that the length of estrous cycle seemed to be consistent to the occurrence of spontaneous alveolar formation (SAF), and that the manifestation of the SAF was controlled by some genetic factors finding the difference in the frequency of the SAF between 15 strains of mice.

Using the stock characteristic of the SAF, the present study deals with the examination on the relationship between the SAF and estrous cycle at successive stages in different ways of keeping mice.

\section{MATERIALS AND METHODS}

Selection has been made for the SAF in the heterozygous stock obtained by the individual selection within $\mathrm{KP} \times \mathrm{dd}$ group for about 4 generations. It is previously described about the KP group (Nagai, 1962). In the stock, the frequency of the SAF was elevated to the level of $74.3 \%$ with the advance of generation.

A total number of 21 mother mice from the stock was used to get the test virgins. The size of the first litters of the mother mice which showed lobule-alveolar system spontaneously at 90 days of age were adjusted to 6 at birth. Young females were separated from males immediately after weaning at 20 days of age. Lamond (1958) and Whitten (1959) reported that mice caged in groups had experienced more abnormal cycles than mice caged singly. Thus in this

Received for publication May 20, 1963. 
experiment female mice were kept in two caging ways, i.e. 1 or 4 animals were caged respectively. All mice were equally exposed to about $8 \mathrm{hrs}$. fluorescent lighting and to male odour in separate cages during the observations. They were fed ad libitum a mixture of pellet (MC-5 Brand prepared by the Oriental Yeast Industry Co.) and smashed barley at a rate of 1 to 3 and some vegetables. Under these conditions the following items were recorded.

Day of vaginal opening and daily vaginal smear

Vaginal opening was examined from 30 days of age. Vaginal smears were taken once daily from 2 or 3 days after the day of vaginal opening to the removal day of mammary gland. Vaginal smears were gently scraped from the dorsoposterior wall of the vagina with a smooth spatula wet with isotonic saline. The end point of the cycle was determined by the appearance of leukocytes in the smear which showed fully cornified cells on the previous day. The procedure employed was that reported by Lamond (1958), Whitten (1959) and Nagai (1962).

\section{Degree of the $S A F$ in the mammary gland}

After observed several cycles, all mice were killed at one stage of age out of $60,70,80$, or 90 days respectively. Some mice were biopsied at either 50 or 60 days of age before autopsy. The third thoracic portion of the left mammary gland was removed from them and wholemounted. Each specimen was examined for the SAF using anatomical microscope $(\times 10)$ and devided into 4 classes according to the degree of alveolar development. Four classes are as follows :

-: Mammary gland showing ducts branching with lateral and end buds without alveolus.

\pm : Mammary gland with alveolar buds.

+: Mammary gland containing a large number of isolated alveoli or several lobules of alveoli.

H: Mammary gland with a large number of lobules of alveoli.

The latter two types $(+$ and $H$ ) were regarded as the pattern exhibiting the positive SAF.

Body weight, ovarian weight and uterine weight

Body weight of $12,20,30,40,50,60,70,80$ and 90 days of age were recorded. Ovarian weight and uterine weight were also recorded immediately after killing. Uterus was lightly pressed against a filter paper before weighing.

\section{RESULTS}

The days of vaginal opening and relationship between the $S A F$ and estrous cycle

The results obtained were set out in Table $1-\mathrm{a}$ and $\mathrm{b}$.

In the grouped mice, the SAF positive mice opened their vaginae about 33 days of age and somewhat earlier than the SAF negative mice. But its difference was not significant statistically.

Mice in 4-animals cage showed more positive SAF than mice caged singly, the frequency of the SAF being influenced greatly by the number of mice within a cage.

Table 1-a. Relationship between the SAF and the age of vaginal opening

\begin{tabular}{|c|c|c|c|c|c|c|c|}
\hline \multicolumn{4}{|c|}{1 mouse per cage } & \multicolumn{4}{|c|}{4 mice per cage } \\
\hline \multicolumn{2}{|r|}{ SAF- } & \multicolumn{2}{|r|}{ SAF+ } & \multicolumn{2}{|r|}{ SAF- } & \multicolumn{2}{|r|}{ SAF +} \\
\hline No. & $M \pm S . E$. & No. & $M \pm S . E$. & No. & $M \pm S . E$. & No. & $M \pm S . E$. \\
\hline 20 & $34.7 \pm 2.9$ days & 2 & $39.0 \pm 0$ days & 19 & $34.0 \pm 0.7$ days & 22 & $32.6 \pm 0.7$ days \\
\hline
\end{tabular}


Table 1-b. Effect of grouping and relationship between the SAF and estrous cycle

\begin{tabular}{|c|c|c|c|c|c|c|c|c|c|c|c|}
\hline \multirow[b]{3}{*}{$\begin{array}{l}\text { Test } \\
\text { day }\end{array}$} & \multirow{3}{*}{$\begin{array}{c}\text { Total } \\
\text { no. of } \\
\text { mice }\end{array}$} & \multicolumn{4}{|c|}{1 mouse per cage } & \multicolumn{6}{|c|}{4 mice per cage } \\
\hline & & \multicolumn{2}{|c|}{ SAF - } & \multicolumn{2}{|r|}{ SAF+ } & \multirow{2}{*}{$\begin{array}{l}\text { Total } \\
\text { No. of } \\
\text { mice }\end{array}$} & \multicolumn{4}{|c|}{ SAF- } & \multirow{2}{*}{$\begin{array}{l}\text { SAF+ } \\
\begin{array}{l}\text { Estrous } \\
\text { cycle }\end{array}\end{array}$} \\
\hline & & No. & $\begin{array}{l}\text { Estrous } \\
\text { cycle }\end{array}$ & No. & $\begin{array}{c}\text { Estrous } \\
\text { cycle }\end{array}$ & & No. & $\begin{array}{l}\text { Estr } \\
\text { cycl }\end{array}$ & $\begin{array}{l}\text { rous } \\
\text { le }\end{array}$ & No. & \\
\hline 50 & 7 & 7 & $1 S \sim 3 S$ & 0 & & 8 & 6 & $15 \sim$ & $-3 S$ & 2 & $1 S \sim 2 S$ \\
\hline 60 & 3 & 3 & $6 S \sim 7 S$ & 0 & & 5 & 1 & $5 S$ & & 4 & $\begin{array}{l}1 S \sim 4 S \\
\quad+1 L \sim 2 L\end{array}$ \\
\hline 70 & 6 & 5 & $6 S \sim 7 S$ & 1 & $6 S$ & 16 & & $\begin{array}{l}(5) 6 \\
(1) 4\end{array}$ & $\begin{array}{l}6 S \sim 9 S \\
4 S+1 L\end{array}$ & 10 & $\begin{array}{l}3 S \sim 7 S \\
\quad+1 L \sim 2 L\end{array}$ \\
\hline 80 & 7 & 6 & $8 S \sim 11 S$ & 1 & $6 S+1 L$ & 12 & & $\begin{array}{l}\text { (4) } 7 \\
\text { (1) } 7\end{array}$ & $\begin{array}{l}7 S \sim 10 S \\
7 S+11\end{array}$ & 7 & $\begin{array}{l}3 S \sim 8 S \\
\quad+1 L \sim 3 L\end{array}$ \\
\hline 90 & 7 & 7 & $12 S \sim 14 S$ & So & & 10 & & $\begin{array}{l}(3) 1 \\
-(4)\end{array}$ & $\begin{array}{r}12 S \sim 13 S \\
5 S \sim 12 S \\
+1 L \sim 2 L\end{array}$ & $\mathrm{~S}_{\mathrm{L}} 3$ & $\begin{array}{c}6 S \sim 9 S \\
+2 L\end{array}$ \\
\hline
\end{tabular}

$S: 4 \sim 8$ days $L: 9 \sim 17$ days

In 1-animal cage, the SAF negative mice showed only normal estrous cycles $(1 \mathrm{~S} \sim 14 \mathrm{~S})$, but one of the SAF positive mice had a long cycle in addition to 6 short cycles.

In the grouped cage, the SAF negative mice showed either mere short cycle or intermingled short and long cycles, whereas the SAF positive mice had at least one long cycle before removal of mammary gland except 2 mice at 50 days of age. In those with the SAF positive, the commencement of long cycle was seen at the stage of 39 to 75 days of age (55.1 days in average), the length of the long cycle being $10.26 \pm 0.27$ days.

Relationship between the SAF and body weight at autopsy

The results are shown in Table 2.

Table 2. Relationship between the SAF and the body weight at autopsy

\begin{tabular}{|c|c|c|c|c|c|c|c|c|}
\hline \multirow[b]{3}{*}{$\begin{array}{l}\text { Test } \\
\text { day }\end{array}$} & \multicolumn{4}{|c|}{1 mouse per cage } & \multicolumn{4}{|c|}{4 mice per cage } \\
\hline & \multicolumn{2}{|c|}{ SAF- } & \multicolumn{2}{|c|}{ SAF+ } & \multicolumn{2}{|r|}{ SAF- } & \multicolumn{2}{|r|}{ SAF+ } \\
\hline & No. & $\begin{array}{l}\text { Body wt. (g) } \\
(M \pm S . E .)\end{array}$ & No. & $\begin{array}{l}\text { dy wt. (g) } \\
(M \pm S . E .)\end{array}$ & No. & $\begin{array}{l}\text { ody wt. (g) } \\
(M \pm S . E .)\end{array}$ & No. & $\begin{array}{r}\text { Body wt. (g) } \\
(M \pm S . E .)\end{array}$ \\
\hline 50 & 7 & $20.3 \pm 0.4$ & 0 & & 6 & $19.4 \pm 0.3$ & 2 & 19.9 \\
\hline 60 & 3 & $25.0 \pm 0.3$ & 0 & & 1 & 21.6 & 4 & $25.0 \pm 0.3$ \\
\hline 70 & 5 & $23.4 \pm 0.4$ & 1 & 23.5 & 6 & $22.7 \pm 0.7$ & 10 & $23.7 \pm 0.7$ \\
\hline 80 & 6 & $23.9 \pm 0.7$ & 1 & 23.9 & 5 & $23.4 \pm 0.6$ & 7 & $25.2 \pm 0.8$ \\
\hline 90 & 7 & $24.6 \pm 0.7$ & 0 & & 7 & $23.7 \pm 0.7$ & 3 & $24.9 \pm 1.4$ \\
\hline
\end{tabular}

Mice in 1-animal cage appeared to be somewhat heavier than those caged 4 in the SAF negative mice.

In the grouped mice, the SAF positive mice were about $25 \mathrm{~g}$ at autopsy and somewhat heavier than the SAF negative mice. But in each case difference was 
not significant statistically.

Relationship between the $S A F$ and ovarian weight and uterine weight

The results are shown in Tables 3 and 4 .

Table 3. Relationship between the SAF and ovarian weight at autopsy

\begin{tabular}{|c|c|c|c|c|c|c|c|c|c|c|c|c|}
\hline \multirow[b]{3}{*}{$\begin{array}{l}\text { Test } \\
\text { day }\end{array}$} & \multicolumn{6}{|c|}{1 mouse per cage } & \multicolumn{6}{|c|}{4 mice per cage } \\
\hline & & SAF- & & & SAF + & & & SAF- & & & SAF+ & \\
\hline & No. & $\begin{array}{l}\text { v. wf. (mg) } \\
(M \pm S . E .)\end{array}$ & $r *^{*}$ & No. & $\begin{array}{l}\text { Ov. wt. (mg) } \\
(M \pm S . E .)\end{array}$ & r.* & No. & $\begin{array}{l}\text { Ov. wt. (r } \\
(M \pm S . E .)\end{array}$ & mg) & No. & $\begin{array}{l}\text { Ov. wt. (m } \\
(M \pm S . E .)\end{array}$ & ng) $r . *$ \\
\hline 60 & 2 & $16.0 \pm 1.0$ & 0.64 & 0 & & & 1 & 12.0 & 0.56 & 2 & 19.0 & 0.76 \\
\hline 70 & 5 & $16.0 \pm 1.7$ & 0.68 & 1 & 25.0 & 1.06 & 6 & $18.2 \pm 1.2$ & 0.80 & 10 & $20.6 \pm 0.9$ & 0.87 \\
\hline 80 & 6 & $17.2 \pm 1.8$ & 0.72 & 1 & 21.0 & 0.88 & 5 & $18.0 \pm 0.9$ & 0.77 & 7 & $22.1 \pm 3.4$ & 0.88 \\
\hline 90 & 7 & $17.1 \pm 1.2$ & 0.70 & 0 & & & 7 & $13.1 \pm 0.6$ & 0.55 & 3 & $17.7 \pm 3.5$ & 0.71 \\
\hline
\end{tabular}

Table 4. Relationship between the SAF and uterine weight at autopsy

\begin{tabular}{|c|c|c|c|c|c|c|c|c|c|c|c|c|}
\hline \multirow[b]{3}{*}{$\begin{array}{l}\text { Test } \\
\text { day }\end{array}$} & \multicolumn{6}{|c|}{1 mouse per cage } & \multicolumn{6}{|c|}{4 mice per cage } \\
\hline & & SAF- & & & $S A F+$ & & & SAF - & & & $\mathrm{SAF}+$ & \\
\hline & No. & $\begin{array}{l}\text { Ut. wt. (mg) } \\
(M \pm S . E .)\end{array}$ & r.* & No. & $\begin{array}{l}\text { Ut. wt. (mg } \\
(M \pm \text { S.E. })\end{array}$ & r.* & No. & $\begin{array}{c}\text { Ut. wt. (mg) } \\
(M \pm \text { S.E. })\end{array}$ & r.* & No & $\begin{array}{r}\text { Ut. wt. (mg } \\
\text { o. } \quad(M \pm S . E .)\end{array}$ & g) $r . *$ \\
\hline 60 & 2 & $85.5 \pm 7.5$ & 3.42 & 0 & & & 1 & 54.0 & 2.50 & 2 & 121.5 & 4.86 \\
\hline 70 & 5 & $84.4 \pm 11.5$ & 3.61 & 1 & 143.0 & 6.09 & 6 & $98.8 \pm 8.8$ & 4.35 & 10 & $115.9 \pm 10.4$ & 4.89 \\
\hline 80 & 6 & $99.4 \pm 11.9$ & 4.16 & 1 & 89.0 & 3.72 & 5 & $78.0 \pm 10.1$ & 3.33 & 7 & $143.9 \pm 18.9$ & 5.71 \\
\hline 90 & 71 & $108.0 \pm 12.0$ & 4.80 & 0 & & & 71 & $113.6 \pm 14.9$ & 4.79 & 3 & $90.3 \pm 16.6$ & 3.63 \\
\hline
\end{tabular}

Ovarian weights of the SAF positive mice were about $20 \mathrm{mg}$ and heavier than those of the SAF negative mice at autopsy. Ovarian weight in the group kept singly was from 11 to $25 \mathrm{mg}$ (60 90 days) whereas that in the other group was from 13 to $26 \mathrm{mg}$ ( $60 \sim 90$ days). In both groups kept either singly or grouped, body weights at autopsy was also heavier in the SAF positive mice than in the SAF negative mice. Ovarian weight/body weight at autopsy was compared. The SAF positive mice appeared to have the large value of the ratio than the SAF negative mice. Uterine weight at autopsy appeared to have the same tendency as ovarian weight.

\section{DISCUSSION}

In the present study, the SAF of the mammary gland appeared to be related closely with long estrous cycles. Long cycles lasted in average for 9 days in the singly caged mice and 10.3 days in the grouped mice. Causes of long cycles in 
grouped mice had been reported by Van der Lee and Boot (1956 and 1957), Lamond (1958) and Whitten (1959). Van der Lee and Boot (1957) ascribed the long cycles to pseudopregnancy because they observed a decidual reaction. However, Lamond (1958) and Whitten (1958) considered that long cycles were due to anestrus, not to pseudopregnancy because an immediate cessation of abnormal cycling was found by the introduction of a male to a female cage (Lamond, 1958) and a decidual reaction was not found in the majority of mice showing abnormal cycle (Whitten, 1958). In the present study almost all the SAF positive mice might experience pseudopregnancy, strictly 'extra-coital' pseudopregnancy called by Dewar (1959), in a view of lobule-alveolar formation in mammary gland, the increase of ovarian, uterine and body weight. Dewar (1957) reported the increase of body weight during pseudopregnancy. Mody and Christian (1962) observed the increase of ovarian weight and in the number of corpora lutea and degeneration of the adrenal X-zone occurred in grouped mice. Many reports coincide on the uterine thickness during pseudopregnancy. Thus it may be suggested that pseudopregnancy have a role in the SAF positive mice used in this experiments.

While lobule-alveolar system in the mammary gland in virgin mice was caused by the hormonal situation at pseudopregnancy, problem was left unsolved because some mice without long cycles showed lobule-alveolar system spontaneously and others with long cycle had not lobule-alveolar system. In regard to the problem, Nagai (1962) proposed the balance hypothesis. He considered that lobule-alveolar system could be developed either in sensitive mammary gland to the hormones or by a large amount of the hormones concerned, and that the balance of two mechanism was important in developing lobule-alveolar system. But many reports are seen in regard to the relationship between adrenal gland and mammary gland, e.g. Folley (1952) reported that DCA together with oestrogen stimulated growth of alveoli. And Sparkes et al. (1955) reported that cortisol promoted a slight development of acini and secretion. If adrenal organ plays a role in developing the SAF, the problem is not so simple. Further examination on the secretion of progesterone is needed for solving this.

Pseudopregnancies in this study may not be caused by stimulating uterus cervix with a spatula, for the frequency of pseudopregnancies are much different between the SAF positive and the negative mice of which smears were taken by the same manner. Dewar (1959) reported that most of the apparently spontaneous pseudopregnancies were not the result of experimental handling but that the occurrence of pseudopregnancy in mice isolated from males most commonly resulted from close proximity to, or contact with, other females. On the other hand, Van der Lee and Boot (1957) showed that excision of the olfactory bulbs greatly reduced the incidence of pseudopregnancies. So, it may be conceivable as the cause of occurrence of long cycles that stimuli from olfactory sense may affect anterior pituitary and then ovary. Whitten (1958) also thought of olfactory stimuli rather than visual or tactile stimuli as the cause for anestrus. The sense of 'Pheromone' in some insects (bee, butterflys, moth etc.) (Karlson and Luscher $1959 \mathrm{a}$ and b) may be brought in this field.

In the present study, mice younger than 3 months often showed the SAF. 
Dewar (1959) reported the SAF in mice older than 3 months. Van der Lee and Boot (1956 and 1957) showed a higher incidence of pseudopregnancies in mice between 6 and 10 months of age. The strain used in the present study may be different genetically from others with respect to causing pseudopregnancies in younger age.

Mody and Christian (1962) reported that the lack of acinar development in the mammary glands of the grouped females indicated absence of spontaneous pseudopregnancy in the strain derived from wild house mice strain. Though they suggested from their observations that there might be an increase in androgens and progestins with grouping. Compairing this, the strain used in the present study may have high sensitivity of mammary gland to low level of progesterone and this may be genetic characteristics.

\section{SUMMARY}

Relationship between the spontaneous lobule-alveolar formation and estrous cycle was observed in mice. Sixty-three virgin mice were devided into two groups: 41 mice were caged four and 22 mice were caged singly.

Those mice were observed daily vaginal smear, body weight at every 10 days of age, ovarian and uterine weight at autopsy and presence or absence of lobulealveolar formation in the mammary gland. Results obtained are as follows.

1. Most of the positive SAF mice experienced long estrous cycles before the examination of the mammary gland. But 3 out of 63 mice showed the positive $\mathrm{SAF}$ without experiencing long estrous cycles and 6 out of 63 mice with long cycles had not showed the positive SAF.

2. The frequency of long estrous cycles and of the positive SAF was much higher in the grouped mice than in the singly caged mice.

3. The vaginae of the positive SAF mice opened somewhat earlier than those of the negative SAF mice.

4. The weight of body, ovary and uterus at autopsy was somewhat heavier in the positive SAF mice than in the negative SAF mice.

\section{REFERENCES}

Dewar, A.D. (1957). J. Endcrinol. 15, 230.

Dewar, A.D. (1959). Ibid. 18, 186.

Folley, S.J. (1952). Marshall's physiology of reproduction 2, 549.

Karlson, P. and M. Luscher (1959a). Nature 183, 55.

Karlson, P. and M. Luscher (1959b). Ibid. 183, 1835.

Khanolkar, V.R. and K.J. Ranadiv (1947). J. Pathol. Bacteriol. 59, 593.

Lamond, D.R. (1958). Proc. Aust. Sci. Anim. Prod. 2, 97.

Mody, J.K. and J.J. Christian (1962). J. Endocrinol. 24, 1.

Nagai, J. (1962). Japan J. Zootech. Sci. 33, 256.

Nandi, S. (1958). J. Natl. Cancer Inst. 21, 1043.

Nandi, S. (1959). Univ. Calif. Publ. Loöl. 65, 1.

Sparkes, L.L., T.A. Daane, T. Hayashida, R.D. Cole, W.R. Lyons and C.H. Li (1955). Cancer 8, 271.

Van der Lee, S. and L.M. Boot (1956). Acta Physiol. et Pharmarcol. Neerl. 4, 442.

Van der Lee, S. and L.M. Boot (1957). Ibid. 5, 213.

Whitten, W.K. (1958). J. Endcrinol. 17, 307.

Whitten, W.K. (1959). Ibid. 18, 102. 